\title{
Czechoslovakia faced with the hostile attitudes of Germany and Italy in 1938
}

Outline of content: The situation of Czechoslovakia in 1938 was lamentable. Standing alone, Czechoslovakia tried to retain its sovereignty at all cost. Germans and Italians, however, more and more certain that no other country would stand up for Prague, were showing themselves increasingly hostile towards Czechoslovakia. The diaries of Joseph Goebbels and Galeazzo Ciano make it possible for us to follow the opinions about the future of the Czechoslovak state.

Keywords: Czechoslovakia 1938, Joseph Goebbels, Galeazzo Ciano, Germany’s foreign policy in the interwar period, Italy's foreign policy in the interwar period

Adolf Hitler's Germany and Benito Mussolini's Italy were avowed enemies of the Czechoslovak state. Joseph Goebbels, the minister of propaganda of the Third Reich, was openly hostile towards Czechoslovakia. So was Galeazzo Ciano, the Italian minister of foreign affairs. Their diaries shed interesting light on the foreign policies of Germany and Italy.

Goebbels noted in his diary on 14 January 1938 that "Bohemia pursues an insane policy. The principle is to be selfish today. This usually leads to disaster tomorrow". He referred amicably to Józef Beck, the Polish minister of foreign affairs, writing that he was "a wise and competent man" and that the "GermanPolish treaty of 26 January 1934 is on the whole operative", but also noted that "Russia is currently unable to make alliances" on account of the purges unleashed by Stalin in the Soviet Union. Goebbels opined that Beck "seems to be a loyal partner too". By contrast, he hurled insults at Czechoslovakia: "Bohemia is really a heap of shit" (noted on 29 January 1938). ${ }^{1}$

Commenting on Hitler's speech in the Reichstag of 20 February 1938, Goebbels pointed out that "the Germans in Czechoslovakia were taken into the care of

${ }^{1}$ J. Goebbels, Dzienniki (Diaries) vol. 1: 1923-1939, Warszawa, 2013, pp. 414-415, 418, 428;

G. Ciano, Dziennik 1937-1943 (Diary 1937-1943), Pułtusk, 2006. 
the Reich. Russia is considered an eternal enemy with whom no reconciliation is possible". On 1 March 1938 Goebbels noted that "Stalin organised show trials against Bukharin, Rykov, Yagoda etc. This is a frenzied tragicomedy, one that can only be found in rotten and morally bankrupt Europe". The German minister remarked on 21 March 1938 that "Poland emerged victorious from the conflict with Lithuania" and that the latter country was "utterly defeated" and immediately established diplomatic relations with Poland. Goebbels also pointed out that "at present, Czechs are slowly but steadily more favourable to Sudeten Germans". "The process, however, is too slow and pursued only for tactical reasons". "It will not help them much", Goebbels said, adding that "the Czechs are lost, they have done all of this too late". On the date of 24 March 1938 he wrote that "Belgium is distancing itself from Prague" and that "nobody wants to have anything in common with Bohemia". "In addition to that, the spin-out German political groupings defect the Prague government and turn to Henlein". "Poor Prague! So little of it will remain" - such was the false sympathy of Goebbels for Bohemian politicians.

In the view of Goebbels, Beck's stance in relations to Lithuania was moderate. He remarked: "this is undoubtedly a realistic politician". Poland protests in Prague against the policy of Comintern - Goebbels noted in his diary on the date of 3 April 1938 and, commenting on the situation, wrote that "Prague has got itself into serious trouble". The talks of Konrad Henlein, the leader of the Sudeten Germans, with the Czechoslovak Prime Minister Milan Hodža did not produce any results. "Henlein was negotiating with Hodža, but naturally with no result," Goebbels wrote on 7 April 1938. "Those Bohemians have no idea of what is brewing, poor fools", he noted superciliously. On 14 April 1938 Henlein reported to Goebbels: "The Bohemians are anxious. I can hardly restrain my own people".

According to Goebbels, "the resistance of Bohemians will prove ineffectual, although their fortifications are very good. President Edvard Beneš is currently intent on seeking reconciliation, but it is too late. Sudeten Germans want to return to the Reich. Henlein's tactics - always demand more than you can get - has turned out to be successful. We will reach the goal. The Bohemians are more afraid than they love their homeland". On 24 April 1938 Goebbels proposed that the Bohemians should be "gradually tormented" and praised Henlein for "having done his job properly". On 28 April 1938 he remarked that "Prague is seeking support in Paris and London" and opined that Beneš would soon lose the game.

On 7 May 1938 Goebbels noted in his diary that "with regard to the Bohemian question Mussolini has given us [the Germans] an absolutely free hand". On 30 May 1938 Goebbels declared: "we want to gradually remove the Bohemians from Germany, especially from Vienna. They should not serve in the army so they do not continue their destructive work". On 1 June 1938 Hitler characterized the Bohemians as brazen, hypocritical, bigoted and servile people. Goebbels subscribed to this and added that Hitler had further plans concerning them. He prophesied: 
"they will get into utterly serious trouble" and regarded Czechoslovakia to be a "shitty state which must disappear. The sooner, the better". On 17 June 1938, Goebbels reminded Hitler that Beneš "is our fanatical opponent. He is not a man of high calibre. Had it been otherwise, he would have provoked a preemptive war against us after 1933 or sought an agreement. Or, he would do it now at least. But thank God he lacks reason and stature. And so, Prague is heading for its inevitable fate". Goebbels had no doubt that Hitler was "absolutely determined to take on the first opportunity to deal with Prague. And that is right. Otherwise, we will never reach our objective". On 6 July 1938 Goebbels anticipated that the problem of Prague would be resolved before long. He emphasised that "we must stay together with Poland". On 25 July 1938 he stated that "the question of the Sudeten Germans must be solved by force", because "Prague does not want to show consideration". According to Goebbels, Hitler wanted to "avoid war" and "for this reason is making preparations for it with all possible means". He also noted that "the hatred between the Germans and Bohemians is unsurmountable" and added on 1 August 1938: 'what will happen to six million Bohemians once we take over their country? It is going to be a difficult, almost insoluble problem". He emphasised that "Beneš is our main enemy" and 'the [Bohemian] nation is indifferent and counts on the help of others". Hitler 'still ponders on the question of Prague, but in truth he has already resolved it". Goebbels noted in his diary on 22 August 1938 that 'we must not pamper the nations of [Central and Eastern] Europe, particularly the Bohemians and the other similar riff-raff; on the contrary, we shall chase them away at some point. We do not want these nations, we want their countries". On 12 September 1938, Henlein described the Bohemian nation to Goebbels in the following terms: 'to give a state to the Bohemians is pure nonsense". He believed nevertheless that they would engage in fierce fighting for some time only to end up in a complete breakdown. On 15 September 1938, while referring to the relations with Poland, Goebbels stated distrustfully that 'Polish friendship is never to be trusted completely". ${ }^{2}$

On 20 September 1938 Goebbels confided that 'we wiretap the talks between Beneš and his envoy to London Jan Masaryk"; Beneš "has been one of our most despicable adversaries: dangerous, wily, hypocritical and conniving". In the evening" of 3 October 1938 the leaders of the Third Reich met with Hitler, who reviewed the political situation. The Führer "is adamant in his resolve to destroy Bohemia at the earliest convenience. He will do this. This defunct and amorphous creature of a state must fall", Goebbels related. "For we will swallow Bohemia one day. The way to the Balkans must open up". On 10 October 1938 Hitler inspected Bohemian bunkers and came to the conclusion that defeating Bohemia by way of military conflict would cost too much blood: "what we have now is the best we can have". On the date of 22 November 1938 we can find the statement that 'the border has

2 Goebbels, Dzienniki, pp. 418, 428, 440, 441, 444, 447, 448-449, 450, 470, 473, 489, 491. 
been agreed with Prague. We are planning the direct Wrocław-Vienna motorway. Across Bohemia. Little will remain of this sovereign state". ${ }^{3}$

On 6 March 1938 Ciano welcomed Minister Beck in Rome. On that occasion he noted that Beck 'did not seem to be overly philo-German". The latter insisted that in the case of a conflict triggered because of the Bohemian problem, the alliance with France would not work. 'Ultimately - Ciano wrote - we have agreed on an appropriate formula, since the policies of our countries [Poland and Italy] hold proper relations with Germany as their priority. Both countries [Poland and Italy] are in a similar position and have related interests, namely with Yugoslavia, Hungary and Romania". After the annexation of Austria by the German Reich, Mussolini said that an uncertain point had been wiped out of the map of Europe. He indicated three similar points, which - in his view - would share the same fate; he listed them in the following order: Czechoslovakia, Switzerland and Belgium. Ciano also explained that 'we refused to exert pressure on the government in Warsaw [regarding the Polish-Lithuanian crisis] because we know from our own experience the nuisance of the so-called lecturing governments, those who always feel the urge to admonish others and tell them that their steps will make such and such impact". According to the view" of the British Conservative politician Leopold Amery, Czechoslovakia was in parlous situation. He believed that "an intervention with regard to this case would lead to mediocre results. It is like throwing stones at a lion devouring a man. The lion is disturbed, but this will be of no help to the man" - Ciano noted on 14 April 1938.

Ribbentrop told the Italian minister of foreign affairs that "should the question [of Czechoslovakia] be solved by military force, it would be done within a few days, too fast for anyone to react". The German minister also asserted that the Germans "wanted Poland to grow stronger, as this would strengthen the anti-Bolshevik cordon".

On 13 May 1938 Mussolini said to Ciano that the French was "a nation ravaged by alcohol, syphilis and journalism". Ciano, in his turn, told the Czechoslovak envoy in Prague František Chvalkovski that "we wish a peaceful solution to the Bohemian issue, but we are not interested in it directly and therefore, in this case we can take only a neutral stance. We did nothing as regards Austria, how could we act in the case of Prague then? On 21 May 1938 Ciano reported to Mussolini on the situation in Czechoslovakia. Il Duce confirmed that he evinced no interest in the fate of that country. He did not believe that France would mobilise to defend it. Ciano "asserted the neutral stance of Italy as regards the Bohemian question". Mussolini "believed that the Bohemian question was not as threatening as it was commonly seen" - Ciano noted on 22 May 1938. On 26 May 1938 Ciano told the German ambassador Hans Mackensen that Italy's standpoint on the matter was

3 Ibid., pp. 507, 508-511. 
identical as that of the Germans. "We are not interested in the fate of Prague, and at the same time we profess full solidarity with Germany", said the Italian minister of foreign affairs. Ciano remarked that "even though nothing new happened, Il Duce was more pessimistic today and anticipated a conflict. He announced that he would immediately engage in fighting at the side of the Germans". 4

On 27 June 1938 Ciano "spoke to the Czechoslovak Chvalkovsky, to whom I reiterated the same piece of advice: seek reconciliation with Berlin". On 19 August 1938 Italy was notified that 'the German military presume that before long (by the end of September) a military action in Czechoslovakia is inevitable. Everything is supposed to be ready and prepared in great detail. The key role was to be played by air force. In political terms, nothing has been settled as yet. So we must stick to what we agreed [with Germans] in May. We were assured at that time that any recourse to force was out of the question for a few years at the very least". On 20 August 1938 Ciano requested the Italian ambassador in Berlin Bernardo Attolico 'to meet Ribbentrop and ask him for precise information concerning the plans of the Reich's government with regard to Czechoslovakia, so that we could take mobilisation measures on our western border [i.e. with France]. This will resonate with the Germans as it will explain to them how far we are prepared to go. Indeed, the news from Berlin make it possible to anticipate an imminent crisis regarding the Bohemian issue. Will it be possible to contain this conflict and keep it local or will France set fire to the powder keg? In the latter case, we will have no choice but to stand firmly and immediately hand in hand with Germany. Il Duce is ready to take action, so we must know - everything and on time - what is happening". Ciano observed that 'Czechoslovakia is isolated, while the system of alliances of France has turned upside down". 'In keeping with my [Ciano] instructions of 20 August, Attolico spoke to Ribbentrop, who replied ambiguously. They [the Germans] are very keen to take action and everything, or nearly everything, is already prepared, but it seems that the decision has not been made yet". On 17 September 1938 Il Duce told Ciano that he "has decided: if Germany, Prague, Paris and Moscow get involved in the conflict, I will remain neutral. But should Great Britain intervene and thus give the conflict a global and ideological dimension, we will then jump into the fire. Italy and fascism could not remain neutral". On 19 September 1938 Ciano remarked that "the news concerning the Bohemian issue are generally positive. Also Il Duce seems to favour a peaceful solution. On 25 September 1938 Ciano noted in his diary that "Hitler also believes that France and England will not get involved [in fighting]. But if they do, he is ready for confrontation. Moreover, he insists that the military situation of the Axis powers is so favourable at the moment that it may be worth to play the game now, especially as one day it will become inevitable. Il Duce assured that if a general

${ }^{4}$ Ciano, Dziennik, pp. 147, 165, 175, 178, 179, 182, 184, 197, 212, 213, 214, 215, 228, 229, 233, 234, 236, 237. 
conflict breaks out, we will stand with Germany, immediately after England goes to war. However, on 25 September 1938 Ciano admitted that 'neither Il Duce nor myself, even though we did not abet Germany to engage in the conflict, did anything to prevent it from happening". On 28 September 1938 Il Duce telephoned Attolico: "go and tell the Führer that while I take into account that I will stand with him in all circumstances, I propose to postpone the beginning of military action for twenty-four hours. I will then take that time to consider how this issue can be solved". Ciano went on to write that he had informed the Britons that Il Duce accepted Chamberlain's request and proposed a 24-hour delay. During the next audience, Britons passed on to him the missive from Chamberlain to Il Duce as well as a copy of the document addressed to Hitler which presented the proposition of organising a conference of the four powers - it will become known as the Munich Conference. ${ }^{5}$

Translated by Damian Jasiński

\section{Czechoslovakia faced with the hostile attitudes of Germany and Italy in 1938 Abstract}

Adolph Hitler's Germany and Benito Mussolini's Italy were both professed enemies of the Czechoslovak state. Joseph Goebbels, the Minister of Propaganda of the Third Reich, did not try to conceal his negative attitude towards Czechoslovakia any more than the Italian Foreign Minister, Galeazzo Ciano. The diaries of Goebbels and Ciano shed interesting light on foreign policy of Germany and Italy. Neither of the authors did try to conceal his aversion to the policy of Czechoslovakia, when analysing the chain of events on the political scene which, in their view, confirmed their opinion on the weakness of Prague.

Goebbels paid attention to show trials in Russia and to the policy of Poland towards Lithuania, and declared that nothing would save Czechoslovakia. "This state has to disappear - he wrote the sooner, the better". Ciano, on the other hand, noted Benito Mussolini's remarks, who - after the annexation of Austria into Germany - indicated Czechoslovakia, Switzerland and Belgium as the weak points to be erased from the map of Europe. He stressed that Italy was not interested in the fate of Prague. Highly symbolic was the order given by Ciano to the Italian ambassador in Berlin, Bernardo Attolico, to go to Ribbentrop and ask him about precise information on the plans of the Third Reich towards Czechoslovakia to allow Italy to make preparations for mobilisation so as not to be taken unawares.

${ }^{5}$ Ibid., p. 237. 


\section{Чехословакия перед лицом враждебной позиции Германии и Италии в 1938 году Аннотация}

Ярыми врагами чехословацкого государства были Германия Адольфа Гитлера и Италия Бенито Муссолини. Министр пропаганды Третьего Рейха Йозеф Геббельс не таил своего отрицательного отношения к Чехословакии. Подобным образом поступал итальянский министр иностранных дел Галеаццо Чиано. Дневники Геббельса, а также дневники Чиано бросают интересный свет на иностранную политику Германии и Италии. Оба автора не скрывали отвращения к чехословацкой политике, анализируя цепь событий на политической сцене, которые, согласно их мнению, подтверждали тезис о слабости Праги. Геббельс обращал внимание на показательные процессы в России, а также на политику Польши по отношению к Литве и отмечал, что уже ничто не сможет спасти Чехословакию. Это государство должно исчезнуть - писал он - чем скорее тем лучше. Чиано записал замечания Бенито Муссолини, который после аншлюса Австрии Третим Рейхом, указал, как на сомнительные точки, которые следует удалить с карты Европы - Чехословакию, Швейцарию и Бельгию. Он подчеркивал, что Италия не заинтересована в судьбе Праги. Символическим моментом являлось распоряжение Чиано, отданное итальянскому послу в Берлине Бернардо Аттолико, отправиться к Риббентропу и попросить его о точной информации о намерениях правительства Рейха по отношению к Чехословакии, чтобы предпринять возможные мобилизационные шаги.

\section{Bibliography}

Ciano G., Dziennik 1937-1943, tł. i oprac. nauk. T. Wituch, Pułtusk, 2006.

Goebbels J., Dzienniki, t. 1: 1923-1939, selection, trans. and notes E.C. Król, Warszawa, 2013.

Marek Kazimierz Kamiński, prof. dr hab., works at the Institute of History of the Polish Academy of Sciences; he specialises in the 20th-century history of Poland and universal history and in the history of international relations; he is the author of numerous publications on Polish-Czechoslovak relations and issues, including Developing of Polish-Czechoslovak Relations in 1948-1960 (Warsaw, 2012), and Sketches from the History of Poland and Czechoslovakia in the 1930s (Warsaw, 2014); the former editor-in-chief of the periodical Studies in the History of Russia and Central-Eastern Europe. 